\title{
Present and future nitrogen deposition to national parks in the United States: critical load exceedances
}

\author{
R. A. Ellis ${ }^{1,2}$, D. J. Jacob ${ }^{1,2}$, M. P. Sulprizio ${ }^{1}$, L. Zhang ${ }^{2,3}$, C. D. Holmes ${ }^{4}$, B. A. Schichtel ${ }^{5}$, T. Blett ${ }^{6}$, E. Porter $^{6}$, \\ L. H. Pardo ${ }^{7}$, and J. A. Lynch $^{8}$ \\ ${ }^{1}$ School of Engineering and Applied Sciences, Harvard University, Cambridge, MA, USA \\ ${ }^{2}$ Department of Earth and Planetary Sciences, Harvard University, Cambridge, MA, USA \\ ${ }^{3}$ Department of Atmospheric and Oceanic Sciences, Laboratory for Climate and Ocean-Atmosphere Studies, \\ School of Physics, Peking University, Beijing, China \\ ${ }^{4}$ Department of Earth System Science, University of California, Irvine, CA, USA \\ ${ }^{5}$ Air Resources Division, National Park Service, Fort Collins, CO, USA \\ ${ }^{6}$ Air Resources Division, National Park Service, Denver, CO, USA \\ ${ }^{7}$ USDA Forest Service, University of Vermont Aiken Center, Burlington, VT, USA \\ ${ }^{8}$ Office of Air and Radiation, United States Environmental Protection Agency, Washington, DC, USA
}

Correspondence to: D. J. Jacob (djj@seas.harvard.edu)

Received: 27 February 2013 - Published in Atmos. Chem. Phys. Discuss.: 5 April 2013

Revised: 29 July 2013 - Accepted: 5 August 2013 - Published: 10 September 2013

\begin{abstract}
National parks in the United States are protected areas wherein the natural habitat is to be conserved for future generations. Deposition of anthropogenic nitrogen $(\mathrm{N})$ transported from areas of human activity (fuel combustion, agriculture) may affect these natural habitats if it exceeds an ecosystem-dependent critical load (CL). We quantify and interpret the deposition to Class I US national parks for present-day and future (2050) conditions using the GEOSChem global chemical transport model with $1 / 2^{\circ} \times 2 / 3^{\circ}$ horizontal resolution over North America. We estimate CL values in the range $2.5-5 \mathrm{~kg} \mathrm{Nha}^{-1} \mathrm{yr}^{-1}$ for the different parks to protect the most sensitive ecosystem receptors. For present-day conditions, we find 24 out of 45 parks to be in CL exceedance and 14 more to be marginally so. Many of these are in remote areas of the West. Most (40-85\%) of the deposition originates from $\mathrm{NO}_{\mathrm{x}}$ emissions (fuel combustion). We project future changes in $\mathrm{N}$ deposition using representative concentration pathway (RCP) anthropogenic emission scenarios for 2050. These feature 52-73\% declines in US $\mathrm{NO}_{\mathrm{x}}$ emissions relative to present but $19-50 \%$ increases in US ammonia $\left(\mathrm{NH}_{3}\right)$ emissions. Nitrogen deposition at US national parks then becomes dominated by domestic $\mathrm{NH}_{3}$ emissions. While deposition decreases in the East relative to present, there is little progress in the West and increases in
\end{abstract}

some regions. We find that 17-25 US national parks will have CL exceedances in 2050 based on the RCP8.5 and RCP2.6 scenarios. Even in total absence of anthropogenic $\mathrm{NO}_{\mathrm{x}}$ emissions, 14-18 parks would still have a CL exceedance. Returning all parks to $\mathrm{N}$ deposition below CL by 2050 would require at least a $50 \%$ decrease in US anthropogenic $\mathrm{NH}_{3}$ emissions relative to RCP-projected 2050 levels.

\section{Introduction}

Nitrogen (N) deposition has greatly increased over the last century due to fossil fuel combustion and production of industrial fertilizer (Aber et al., 2003; Fenn et al., 2003b; Galloway et al., 2004). Excess deposition of $\mathrm{N}$ to natural ecosystems can decrease biodiversity, disrupt soil nutrient cycling, and cause acidification and eutrophication of waters (Driscoll et al., 2001; Fenn et al., 2003a; Galloway et al., 2003). This excess deposition is of particular concern in US national parks, where legislation dictates that natural resources be preserved unimpaired (NPS, 2001). Here we use a nested continental/global chemical transport model (GEOSChem CTM) to examine the sources and processes contributing to present and future (2050) $\mathrm{N}$ deposition to US national 
Table 1. GEOS-Chem $\mathrm{NO}_{\mathrm{x}}$ and $\mathrm{NH}_{3}$ emissions over the contiguous US for 2006.

\begin{tabular}{|c|c|c|}
\hline Source & Emission ( $\mathrm{Tg} \mathrm{N}$ yr & \\
\hline \multirow[t]{7}{*}{$\mathrm{NO}_{\mathrm{x}}$} & Fuel combustion ${ }^{a}$ & 5.0 \\
\hline & Aircraft & 0.13 \\
\hline & Lightning & 0.56 \\
\hline & Soil & 0.40 \\
\hline & Fertilizer & 0.13 \\
\hline & Wildfires & 0.05 \\
\hline & Total & 6.3 \\
\hline \multirow[t]{4}{*}{$\mathrm{NH}_{3}$} & Anthropogenic ${ }^{\mathrm{b}}$ & 2.8 \\
\hline & Wildfires & 0.04 \\
\hline & Other natural $^{\mathrm{c}}$ & 0.52 \\
\hline & Total & 3.3 \\
\hline
\end{tabular}

parks, identifying parks that exceed thresholds for detrimental ecosystem impact.

Elevated $\mathrm{N}$ deposition from human activity is mainly driven by emissions of nitrogen oxides $\left(\mathrm{NO}_{\mathrm{x}} \equiv \mathrm{NO}+\mathrm{NO}_{2}\right)$ and ammonia $\left(\mathrm{NH}_{3}\right)$ (Table 1). $\mathrm{NO}_{\mathrm{x}}$ is produced in combustion by oxidation of atmospheric $\mathrm{N}_{2}$ and fuel nitrogen. It is oxidized in the atmosphere on a timescale of a day to nitric acid $\left(\mathrm{HNO}_{3}\right)$, which is removed rapidly by wet and dry deposition. The major source of $\mathrm{NH}_{3}$ is from livestock manure. $\mathrm{NH}_{3}$ is also produced industrially as fertilizer from reaction of $\mathrm{N}_{2}$ and $\mathrm{H}_{2}$ (Haber-Bosch process). Part of this $\mathrm{NH}_{3}$ is lost to the atmosphere upon fertilizer application. Soil cycling of fertilizer $\mathrm{N}$ is also a source of $\mathrm{NO}_{\mathrm{x}} \cdot \mathrm{NH}_{3}$ is removed rapidly from the atmosphere by wet and dry deposition, similarly to $\mathrm{HNO}_{3}$. Both $\mathrm{HNO}_{3}$ and $\mathrm{NH}_{3}$ can partition into particles, promoting long-range transport as particle dry deposition is slow.

Emissions (2006) in the contiguous US are estimated to be $6.3 \mathrm{Tg} \mathrm{Na}^{-1}$ for $\mathrm{NO}_{\mathrm{x}}$ and $3.3 \mathrm{Tg} \mathrm{Na} \mathrm{N}^{-1}$ for $\mathrm{NH}_{3}$, with anthropogenic sources contributing about $85 \%$ of the total for both species (Zhang et al., 2012). $\mathrm{NO}_{\mathrm{x}}$ emissions have decreased by 55\% from 1992 to 2012 (NEI: http://www.epa.gov/ttnchie1/trends/), due to national regulations targeting ground-level ozone and acid deposition. $\mathrm{NH}_{3}$ emission trends are more uncertain although measurements of ammonium $\left(\mathrm{NH}_{4}^{+}\right.$) wet deposition fluxes provide useful constraints (Gilliland et al., 2006; Pinder et al., 2006; Zhang et al., 2012), these measurements show a statistically significant increase nationally over the past four decades (Lehmann et al., 2007). Recently, Xing et al. (2012) developed spatially resolved emission inventories for the US from 1990 to 2010 and found $\mathrm{NH}_{3}$ emissions to have increased by $11 \%$ over that period.
The National Park Service (NPS) was established in 1916 under the Organic Act, which states as fundamental for national parks to "conserve the scenery and the natural and historic objects and wildlife therein, and to provide for the enjoyment of the same in such manner and by such means as will leave them unimpaired for the enjoyment of future generations" (NPS, 2001). Perturbation of park ecosystems by anthropogenic $\mathrm{N}$ deposition violates this charter. However, the NPS has no authority to control sources outside of the lands that it manages. The $\mathrm{N}$ deposited to NPS lands may originate hundreds or thousands of kilometers away, which complicates source attribution and regulation. There is a currently a concerted effort between the NPS, the US Environmental Protection Agency (EPA), and the state of Colorado to protect resources at Rocky Mountain NP from N deposition (Porter and Johnson, 2007; RMNPI, 2007).

Determining the impact of anthropogenic $\mathrm{N}$ deposition in national parks requires some knowledge of the link between deposition and ecosystem response. This can be expressed in terms of a critical load threshold, as an annual deposition flux in $\mathrm{kg} \mathrm{Nha}^{-1} \mathrm{yr}^{-1}$, below which significant ecosystem damage does not occur. Research on $\mathrm{N}$ deposition and critical loads has been carried out at a number of national parks (Porter and Johnson, 2007). A focused field intensive supported by regional modeling was conducted for Rocky Mountain NP during the Rocky Mountain Airborne Nitrogen and Sulfur Study (RoMANS) in spring-summer 2006 (Beem et al., 2010; Gebhart et al., 2011; Rodriguez et al., 2011). Measurements of dry deposition are particularly difficult and limited. A continental-scale model analysis evaluated with relevant observations, as presented here, can provide a general perspective on $\mathrm{N}$ deposition to US national parks as well as projections for the future.

\section{Methods}

We use the GEOS-Chem CTM v9-01-01 (http://www. geos-chem.org) in a continental-scale simulation of North America with $1 / 2^{\circ} \times 2 / 3^{\circ}$ horizontal resolution, nested within a global simulation with $2^{\circ} \times 2.5^{\circ}$ resolution (Chen et al., 2009) and driven by GEOS-5 meteorological data for 2006-2008 from the Goddard Earth Observing System (GEOS) of the NASA Global Modeling and Assimilation Office. Our simulation largely follows the work of Zhang et al. (2012), who used the same nested modeling approach with GEOS-Chem v8-02-03 to estimate $\mathrm{N}$ deposition over the US for 2006-2008. The reader is referred to that paper for a detailed model description; here we will only give a brief summary and elaborate on the differences.

Table 1 gives total $2006 \mathrm{NO}_{\mathrm{x}}$ and $\mathrm{NH}_{3}$ emissions for the US, which are $5 \%$ lower for $\mathrm{NO}_{\mathrm{x}}$ than Zhang et al. (2012) and $10 \%$ higher for $\mathrm{NH}_{3}$ due to the use of slightly different interannual scaling factors for anthropogenic sources. Figure 1 (top) shows the distribution 


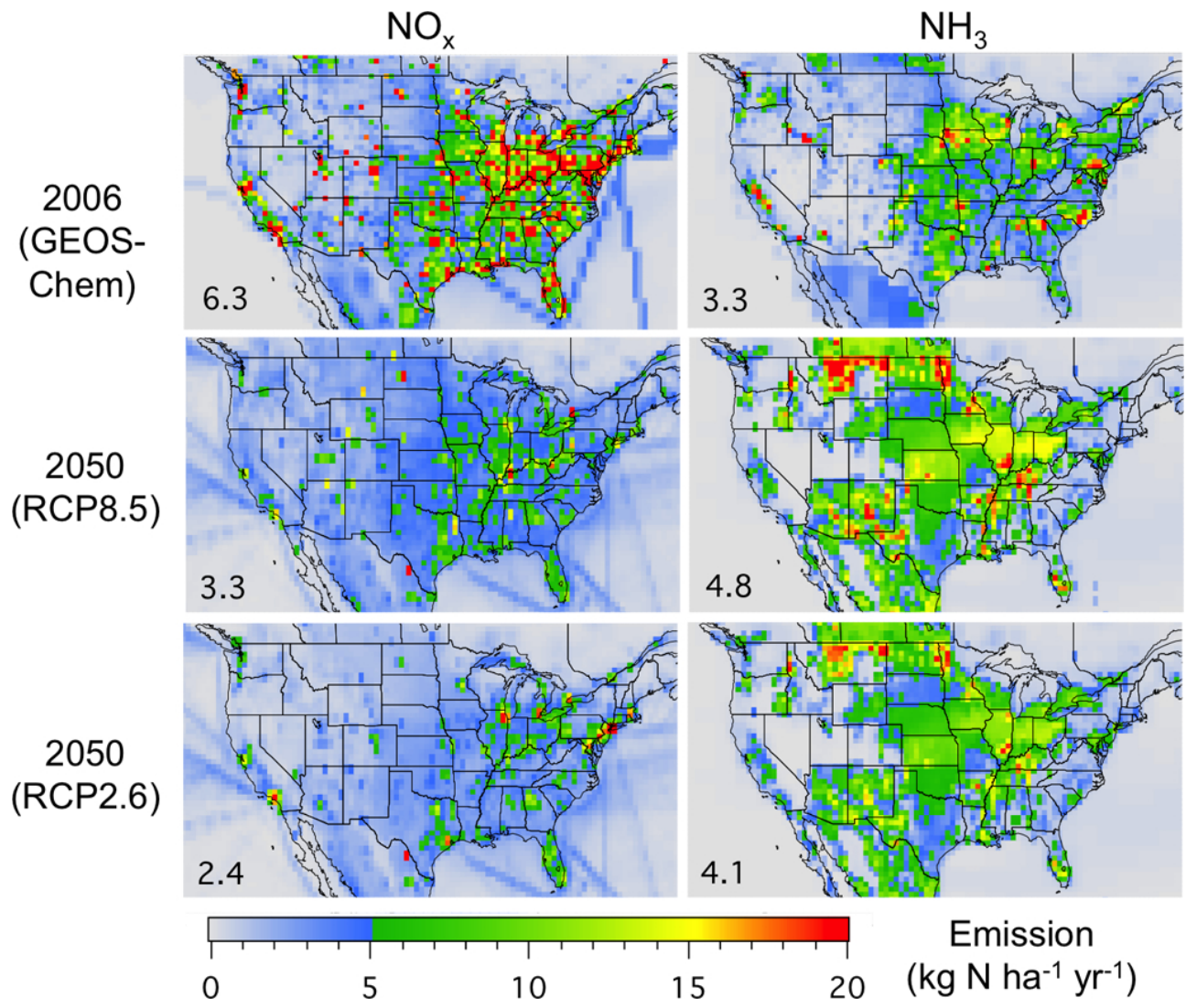

Fig. 1. $\mathrm{NO}_{\mathrm{x}}$ and $\mathrm{NH}_{3}$ emissions in North America for 2006 and 2050. Numbers inset give contiguous US totals (Tg $\mathrm{Nyr}^{-1}$ ). Year 2050 emissions are from the RCP8.5 and RCP2.6 scenarios (see text).

of emissions. Anthropogenic emissions for the US are based on the EPA National Emission Inventory for 2005 (www.epa.gov/ttnchie1/net/2005inventory.html), the CAC inventory for Canada (www.ec.gc.ca/inrp-npri/) and the BRAVO inventory for Mexico (Kuhns et al., 2005). Previous studies have revealed regional/seasonal underestimates of $\mathrm{NH}_{3}$ emissions in GEOS-Chem (Fisher et al., 2011; Heald et al., 2012; Walker et al., 2012; Zhu et al., 2013). A global inversion of wet deposition flux data by Paulot et al. (2013b) using GEOS-Chem yields an optimal $\mathrm{NH}_{3}$ emission estimate of $2.8 \mathrm{Tg} \mathrm{N} \mathrm{yr}^{-1}$ for the contiguous US, as compared to $3.3 \mathrm{Tg} \mathrm{N} \mathrm{yr}^{-1}$ used here.

Nitrogen deposition in the model includes wet and dry contributions from $\mathrm{NO}_{\mathrm{y}}\left(\mathrm{NO}_{\mathrm{x}}+\right.$ nitrates $)$ and $\mathrm{NH}_{\mathrm{x}}\left(\mathrm{NH}_{3}\right.$ gas $+\mathrm{NH}_{4}^{+}$aerosol). Zhang et al. (2012) give a breakdown of the contributions of different processes to deposition averaged over the continuous US: wet $\mathrm{NO}_{3}^{-}(20 \%)$, wet $\mathrm{NH}_{4}^{+}(20 \%)$, dry $\mathrm{NO}_{\mathrm{y}}(44 \%)$, and dry $\mathrm{NH}_{\mathrm{x}}(16 \%)$. Most of the dry $\mathrm{NO}_{\mathrm{y}}$ deposition is as $\mathrm{HNO}_{3}$. Updates to the GEOS-Chem wet deposition simulation in v9-01-01 include allowance for rainout and washout to occur in the same model grid box (Wang et al., 2011). This does not change significantly the deposition patterns compared to Zhang et al. (2012).
Zhang et al. (2012) presented an extensive evaluation of GEOS-Chem $\mathrm{N}$ deposition with observations over the United States for 2006 including comparisons with the NADP network (wet deposition), the IMPROVE and CASTNet networks $\left(\mathrm{NO}_{3}^{-}\right.$and $\mathrm{NH}_{4}^{+}$aerosol concentrations, $\mathrm{HNO}_{3}$ gas concentrations), $\mathrm{NO}_{2}$ columns from the OMI satellite instrument, and other data. We focus our model evaluation here on the wet deposition flux data in the US national parks.

The National Atmospheric Deposition Program (NADP; http://nadp.sws.uiuc.edu) measures wet deposition of $\mathrm{NO}_{3}^{-}$ and $\mathrm{NH}_{4}^{+}$at 29 of the 45 parks in the contiguous US. Figure 2 compares simulated and observed nitrate $\left(\mathrm{NO}_{3}^{-}\right)$and ammonium $\left(\mathrm{NH}_{4}^{+}\right)$wet deposition fluxes for 2006-2008 at the ensemble of Class I US national park sites with NADP monitors. The model shows strong correlation with observations for both species and no significant national bias. Zhang et al. (2012) found similar agreement in their comparisons for the ensemble of NADP sites, with some degradation when considering seasonal variations. The highest wet deposition fluxes in Fig. 2 are at Cuyahoga Valley NP in Ohio, both in the model and in the observations. At this site the model is $35 \%$ too high for $\mathrm{NO}_{3}^{-}$, which is mostly a winter bias and may be related to model chemistry (Zhang et al., 2012; Paulot et al., 2013a). Wet deposition over California is relatively 

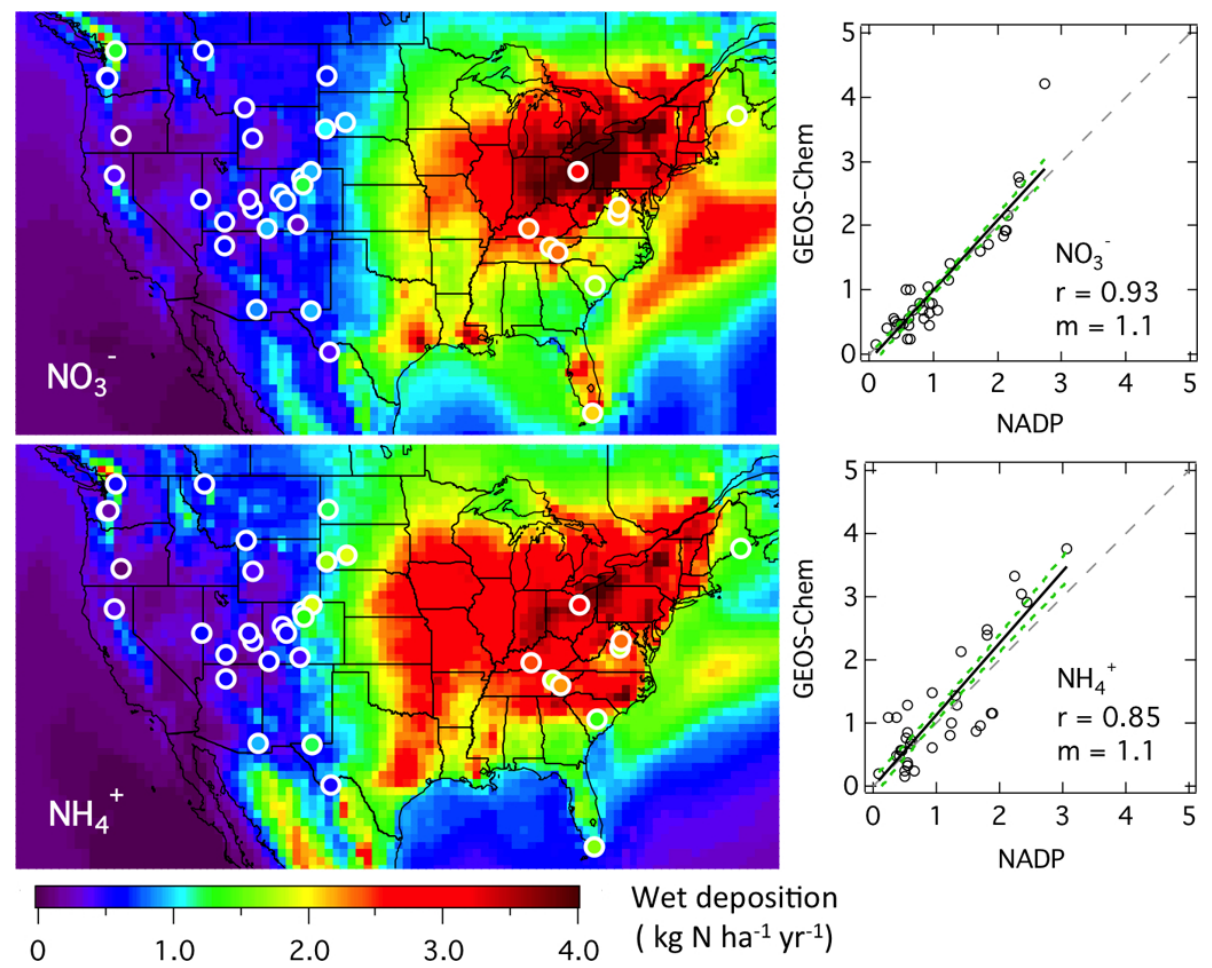

Fig. 2. Annual mean wet deposition fluxes of nitrate $\left(\mathrm{NO}_{3}^{-}\right)$and ammonium $\left(\mathrm{NH}_{4}^{+}\right)$for 2006-2008. GEOS-Chem model results (background) are compared to observations from the National Atmospheric Deposition Program (NADP) at national parks (circles). Scatterplots are given in the right panels with correlation coefficients $(r)$, reduced-major axis regression slopes $(m)$, and bootstrap errors on the slopes in green. The $1: 1$ line is also shown as dashed. Note that not all national parks have NADP monitors.

low in the model and observations, even though emissions are high, because of low precipitation. Deposition there is mostly in dry form as will be discussed below.

\subsection{Critical loads}

The critical load (CL) is defined as "the quantitative estimate of an exposure to one or more pollutants below which significant harmful effects on specified sensitive elements of the environment do not occur according to present knowledge" (Nilsson and Grennfelt, 1988). For a given national park, different CLs may apply depending on the specified elements, commonly referred to as receptors (Pardo et al., 2011b). For example, CLs are different for alpine lakes (Baron, 2006; Saros et al., 2011), for lichens in forests (Geiser et al., 2010), and for alpine vegetation and soils (Bowman et al., 2012). CLs can also depend on the type of harmful effect. For example, in alpine lakes, different CLs might apply for changes in diatom assemblages and for surface water acidification (Baron, 2006). CLs for nitrogen are normally based on inorganic $\mathrm{N}$ deposition, because very few studies report inputs of organic N (Pardo et al., 2011a). More than $20 \%$ of total N deposition at Rocky Mountain NP could be from organic N (Beem et al., 2010). Thus CL estimates are likely conservative (Cape et al., 2011). Our GEOS-Chem estimates of $\mathrm{N}$ de- position do not include organic $\mathrm{N}$ except for organic nitrates originating from $\mathrm{NO}_{\mathrm{x}}$ atmospheric oxidation, and these account for less than $10 \%$ of total $\mathrm{NO}_{\mathrm{y}}$ deposition (Zhang et al., 2012). For a comprehensive discussion of the concept and use of CLs we refer the reader to Porter et al. (2005), Groffman et al. (2006), and Burns et al. (2008).

Information on CLs in national parks is sparse, and often needs to be extrapolated from data in other regions. Recently, Pardo et al. (2011a) synthesized research on $\mathrm{N}$ deposition effects on ecosystems. They estimated CLs in the US for Level I Ecoregions as defined by the Commission for Environmental Cooperation (CEC, 1997). They reported a range of CLs for each ecoregion including multiple receptors.

Here, we set the CL for a national park as the CL for the most sensitive ecosystem receptor identified in the corresponding ecoregion. Our rationale is that the parks need by statute to be fully protected in their natural state. Often, the $\mathrm{CL}$ for a receptor includes a range of values that represent different responses to $\mathrm{N}$ deposition (Pardo et al., 2011a). We then choose the low end of the range to provide the most conservative estimate. Pardo et al. (2011a) also gives confidence levels for the range of $\mathrm{CL}$ values. For the receptors used here, the confidence levels are either in the reliable or fairly reliable category. The lowest CL across Level I Ecoregions is generally for lichens, which are highly $\mathrm{N}$ sensitive (Geiser 


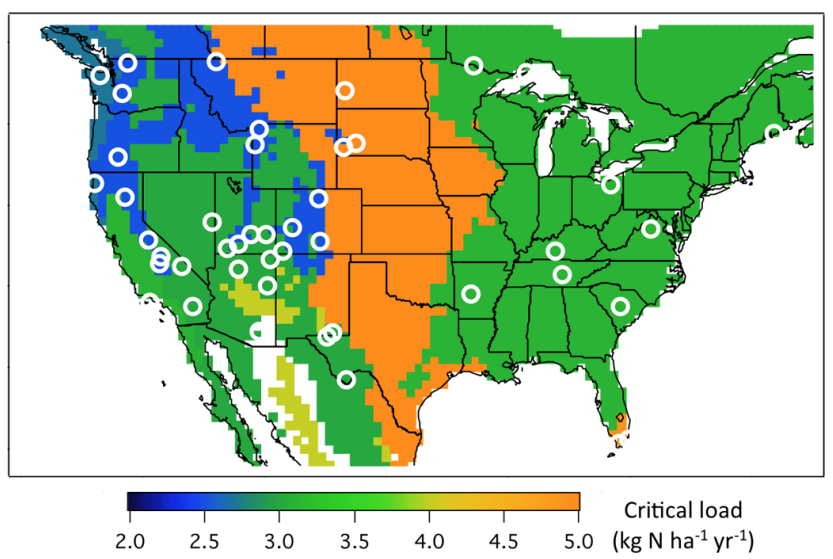

Fig. 3. CL values for nitrogen deposition in different US ecoregions, based on estimates from Pardo et al. (2011a) to protect the most sensitive ecosystem elements. White circles indicate locations of US national parks. See text for details.

et al., 2010). Changes to lichen communities may signal the beginning of other ecosystem changes that can eventually alter the function and structure of the community as a whole (Pardo et al., 2011a). It is conceivable that our CL estimates may still be too high, considering that long-term effects are poorly understood and the most sensitive receptors may not have been identified (Pardo et al., 2011a).

Figure 3 shows our CL estimates for the US, mapped onto the $1 / 2^{\circ} \times 2 / 3^{\circ}$ grid of GEOS-Chem. Table 2 shows the values for each of the national parks. Values are in the range 2.5$5 \mathrm{~kg} \mathrm{Nha}^{-1} \mathrm{yr}^{-1}$, lower than the $10 \mathrm{~kg} \mathrm{Nha}^{-1} \mathrm{yr}^{-1}$ value commonly assumed in $\mathrm{N}$ deposition modeling studies (Lamarque et al., 2005; Dentener et al., 2006) but based on less sensitive European ecosystems (Pardo et al., 2011a).

\section{Nitrogen deposition and critical load exceedances}

Figure 4 (top) shows GEOS-Chem total annual $\mathrm{N}$ deposition (wet + dry) for 2006, which we take as representative of present day. There is little 2006-2008 interannual variability in the model (Zhang et al., 2012). Table 2 shows the amount of $\mathrm{N}$ deposition simulated by the model for each of the 45 Class I national parks in the contiguous US. Deposition exceeds $10 \mathrm{~kg} \mathrm{Nha}^{-1} \mathrm{yr}^{-1}$ in much of the eastern US and is typically $1-5 \mathrm{~kg} \mathrm{Nha}^{-1} \mathrm{yr}^{-1}$ in the West. Some urban/agricultural areas in the West exhibit higher $\mathrm{N}$ deposition. Rocky Mountain NP receives $4.4 \mathrm{~kg} \mathrm{~N} \mathrm{ha}^{-1} \mathrm{yr}^{-1}$ in the model, which is similar to the value of $4.1 \mathrm{~kg} \mathrm{Nha}^{-1} \mathrm{yr}^{-1}$ previously derived by Baron et al. (2011) using observations from NADP and modeled dry deposition values.

The middle panel in Fig. 4 shows the percent contribution of ammonia $\left(\mathrm{NH}_{\mathrm{x}}\right)$ to $\mathrm{N}$ deposition as computed by GEOSChem. This contribution ranges from 15 to $60 \%$ in the national parks. National parks tend to be located away from agricultural areas so that $\mathrm{NO}_{\mathrm{y}}$ deposition usually dominates.
We find that $\mathrm{NH}_{\mathrm{x}}$ accounts for $54 \%$ of total $\mathrm{N}$ deposition at Rocky Mountain NP, which agrees with the value of $57 \%$ from the RoMANS experimental study (Beem et al., 2010).

The bottom panel in Fig. 4 gives the percent contribution of wet deposition to total $\mathrm{N}$ deposition. Values in the national parks range from 10 to $70 \%$. They reflect not only the frequency of precipitation but also the fraction contributed by ammonia, since the wet/dry deposition ratio is higher for $\mathrm{NH}_{\mathrm{x}}$ than for $\mathrm{NO}_{\mathrm{y}}$ (Zhang et al., 2012). Our results for Rocky Mountain NP agree with the experimental study of Beem et al. (2010), which found most of the deposition there to be wet. However, we see from Fig. 4 that dry deposition dominates for most national parks.

Most of the present-day N deposition to US national parks is anthropogenic in origin according to GEOS-Chem. Zhang et al. (2012) previously estimated that domestic anthropogenic emissions contribute $81 \%$ of $\mathrm{NO}_{\mathrm{y}}$ deposition and $71 \%$ of $\mathrm{NH}_{\mathrm{x}}$ deposition over the contiguous US on an annual basis, with natural source contributions ranging from $10 \%$ in the northeast to $30 \%$ in the Intermountain West. Paulot et al. (2013a) used the adjoint of GEOS-Chem to determine the sources contributing to $\mathrm{N}$ deposition in biodiversity hotspots worldwide including two US national parks, Rocky Mountain and Cuyahoga Valley. They found $\mathrm{N}$ deposition at these two parks to be mainly of domestic anthropogenic origin.

Figure 5 (top) gives present-day CL exceedances over the contiguous US by comparing present-day $\mathrm{N}$ deposition (Fig. 4) to the CLs in Fig. 3. White areas have $\mathrm{N}$ deposition below the CL. Colored areas have CL exceedance by the indicated amount. We find that deposition exceeds the $\mathrm{CL}$ at 24 parks, indicated by the red circles in Fig. 5. An additional 14 parks fall into what we call a "marginal CL exceedance" category, as they would have a CL exceedance based on the model deposition in an adjacent $1 / 2^{\circ} \times 2 / 3^{\circ}$ model grid square ( $\sim 50 \mathrm{~km}$ away).

The highest $\mathrm{CL}$ exceedance $\left(15 \mathrm{~kg} \mathrm{Nha}^{-1} \mathrm{yr}^{-1}\right)$ is for Cuyahoga Valley NP in Ohio. The CL exceedance is also high for all other parks in the eastern US except southern Florida (marginal). Many national parks in the Intermountain West also have a CL exceedance or are marginal, including all California parks except Death Valley. Our results for California are similar to Fenn et al. (2010), who used simulations with the CMAQ regional CTM to diagnose areas with CL exceedance. They used a lichen-based CL of $3.1 \mathrm{~kg} \mathrm{Nha}^{-1} \mathrm{yr}^{-1}$, as compared to our value of 2.5$3 \mathrm{~kg} \mathrm{Nha}^{-1} \mathrm{yr}^{-1}$.

\section{Future nitrogen deposition}

Changing emissions of $\mathrm{NO}_{\mathrm{x}}$ and $\mathrm{NH}_{3}$ over the coming decades may have important implications for $\mathrm{N}$ deposition and CL exceedances in US national parks. We project $\mathrm{N}$ deposition over the US in 2050 using the representative concentration pathway (RCP) projections of anthropogenic 


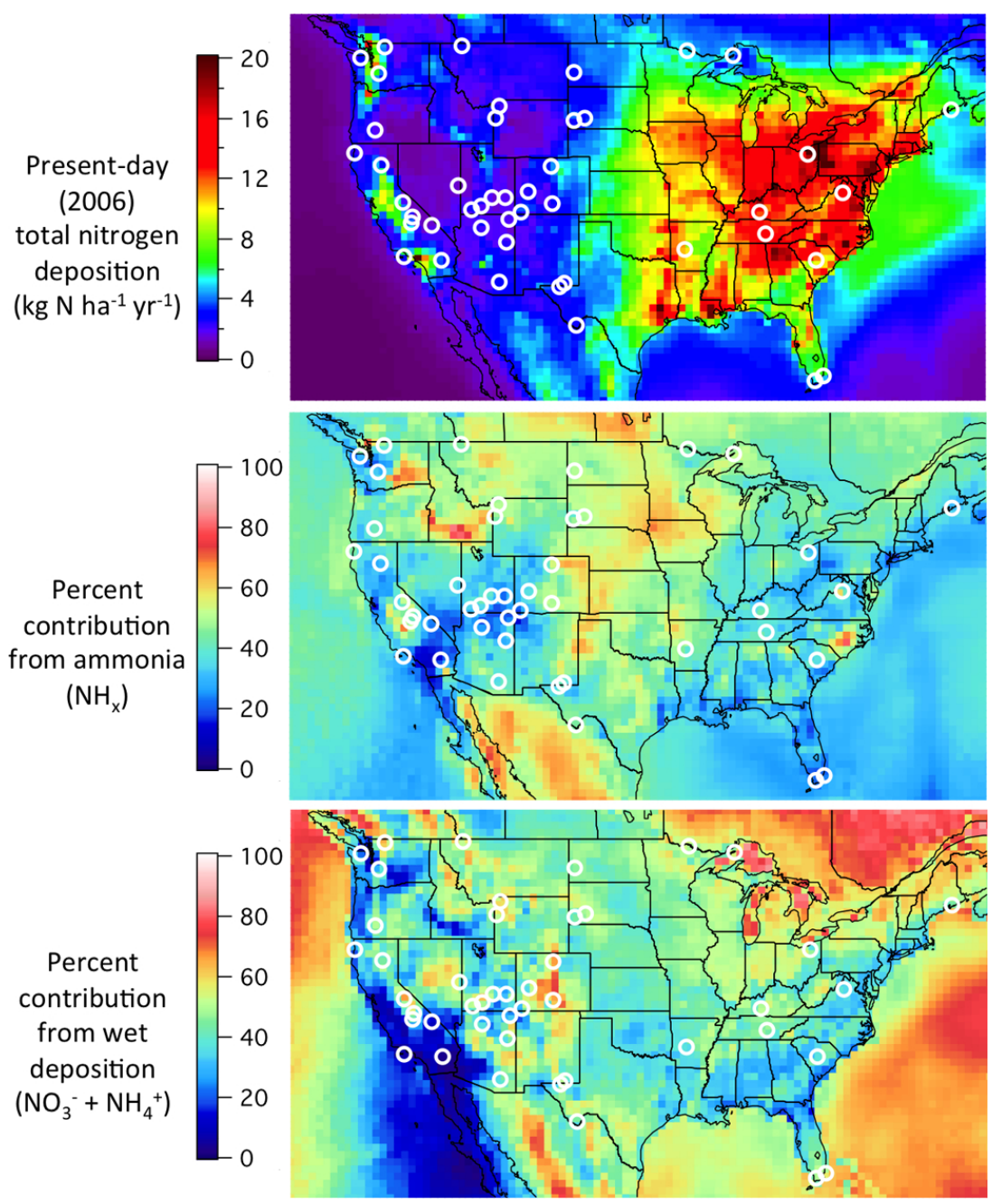

Fig. 4. Total annual (2006) nitrogen deposition over the US simulated by GEOS-Chem (top panel), with percent contribution from ammonia (middle panel), and percent contribution from wet deposition (bottom panel). Circles indicate locations of US national parks.

emissions (van Vuuren et al., 2011). The RCPs are four scenarios (RCP8.5, RCP6, RCP4.5, RCP2.6) that assume increasing emission controls for air quality as well as climate regulations targeted to a radiative forcing endpoint of 8.5 , $6.0,4.5$, or $2.6 \mathrm{~W} \mathrm{~m}^{-2}$ by 2100 (van Vuuren et al., 2011). Each RCP emission scenario derives from an ensemble of integrated assessment models that make diverse socioeconomic and technological development assumptions to achieve the radiative forcing targets (Moss et al., 2010).

The implementation of RCP emissions into GEOS-Chem follows Holmes et al. (2013). Annual RCP emissions for 2050 were downloaded at $0.5^{\circ} \times 0.5^{\circ}$ resolution from the RCP database (https://tntcat.iiasa.ac.at:8743/RcpDb/), and regridded to the GEOS-Chem global $2^{\circ} \times 2.5^{\circ}$ and nested North American $1 / 2^{\circ} \times 2 / 3^{\circ}$ resolution grids. The RCP scenarios also include land use change in response to socioeconomic and energy policy changes, which would affect dry deposition but we do not consider that effect here.
Figure 6 compares the 2050 anthropogenic emissions from the RCP scenarios to present-day values, globally and for the contiguous US. Present-day values from GEOSChem (2006) are compared to interpolated 2000-2010 RCP values for reference. These show excellent agreement in the US and thus we may view GEOS-Chem as consistent with RCP. For $\mathrm{NO}_{\mathrm{x}}$, emissions agree spatially as well but for $\mathrm{NH}_{3}$ there are some small regional differences.

RCP scenarios for 2050 project large decreases of US $\mathrm{NO}_{\mathrm{x}}$ emissions relative to 2006 , from 52 to $73 \%$ depending on the scenario, reflecting emission controls to abate surface ozone as well as changes in the energy mix. Global anthropogenic $\mathrm{NO}_{\mathrm{x}}$ emissions show a less dramatic decrease (14$28 \%$ ) from 2006 to 2050 across all scenarios, as emission controls are offset by industrialization.

$\mathrm{NH}_{3}$ emissions increase from 2006 to 2050 for all RCP scenarios, both in the US (19-50\%) and globally (26-57\%). There is little difference in $\mathrm{NH}_{3}$ emissions across scenarios, 
Table 2. Nitrogen deposition and critical loads in US national parks.

\begin{tabular}{|c|c|c|c|c|}
\hline National Park & Ecoregion $^{\mathrm{a}}$ & Receptor & $\begin{array}{l}\text { Critical Load } \\
\mathrm{kg} \mathrm{Nha}^{-1} \mathrm{a}^{-1}\end{array}$ & $\begin{array}{r}\text { GEOS-Chem } \\
\text { deposition (2006) } \\
\mathrm{kg} \mathrm{N} \mathrm{ha}^{-1} \mathrm{a}^{-1}\end{array}$ \\
\hline Acadia, $\mathrm{ME}\left(44^{\circ} \mathrm{N}, 68^{\circ} \mathrm{W}\right)$ & Eastern Temperate Forests & Hardwood forest & $3-8(\mathrm{R})$ & 6.8 \\
\hline Arches, UT $\left(39^{\circ} \mathrm{N}, 110^{\circ} \mathrm{W}\right)$ & North American Deserts & Herbaceous plants & $3-8.4(\mathrm{~F})$ & 1.9 \\
\hline Badlands, SD $\left(44^{\circ} \mathrm{N}, 102^{\circ} \mathrm{W}\right)$ & Great Plains & Tallgrass prairie & $5-15(\mathrm{~F})$ & 3.2 \\
\hline Big Bend, TX $\left(29^{\circ} \mathrm{N}, 103^{\circ} \mathrm{W}\right)$ & North American Deserts & Herbaceous plants & $3-8.4(\mathrm{~F})$ & 2.8 \\
\hline Biscayne, FL $\left(26^{\circ} \mathrm{N}, 80^{\circ} \mathrm{W}\right)$ & Tropical Wet Forests & Forest/trees & $5-10(\mathrm{E})$ & 4.7 \\
\hline Black Canyon, $\mathrm{CO}\left(39^{\circ} \mathrm{N}, 108^{\circ} \mathrm{W}\right)$ & Eastern Temperate Forests & Hardwood forest & $3-8(\mathrm{R})$ & 2.4 \\
\hline Bryce Canyon, UT $\left(38^{\circ} \mathrm{N}, 112^{\circ} \mathrm{W}\right)$ & North American Deserts & Herbaceous plants & $3-8.4(\mathrm{~F})$ & 1.9 \\
\hline Canyonlands, UT $\left(38^{\circ} \mathrm{N}, 110^{\circ} \mathrm{W}\right)$ & North American Deserts & Herbaceous plants & $3-8.4(\mathrm{~F})$ & 2 \\
\hline Capitol Reef, UT $\left(38^{\circ} \mathrm{N}, 111^{\circ} \mathrm{W}\right)$ & North American Deserts & Herbaceous plants & $3-8.4(\mathrm{~F})$ & 2 \\
\hline Carlsbad Caverns, $\mathrm{NM}\left(32^{\circ} \mathrm{N}, 104^{\circ} \mathrm{W}\right)$ & North American Deserts & Herbaceous plants & $3-8.4(\mathrm{~F})$ & 3.1 \\
\hline Channel Islands, $\mathrm{CA}\left(34^{\circ} \mathrm{N}, 119^{\circ} \mathrm{W}\right)$ & Mediterranean California & Lichens & $3.1-5.2(\mathrm{R})$ & 3.1 \\
\hline Congaree, $\mathrm{SC}\left(34^{\circ} \mathrm{N}, 81^{\circ} \mathrm{W}\right)$ & Eastern Temperate Forests & Hardwood forest & $3-8(\mathrm{R})$ & 11.5 \\
\hline Crater Lake, OR $\left(43^{\circ} \mathrm{N}, 122^{\circ} \mathrm{W}\right)$ & NW Forested Mountains & Lichens & $2.5-7.1(\mathrm{R})$ & 1.9 \\
\hline Cuyahoga Valley, $\mathrm{OH}\left(41^{\circ} \mathrm{N}, 82^{\circ} \mathrm{W}\right)$ & Eastern Temperate Forests & Hardwood forest & $3-8(\mathrm{R})$ & 17.8 \\
\hline Death Valley, CA $\left(36^{\circ} \mathrm{N}, 117^{\circ} \mathrm{W}\right)$ & North American Deserts & Herbaceous plants & $3-8.4(\mathrm{~F})$ & 1.8 \\
\hline Everglades, FL $\left(25^{\circ} \mathrm{N}, 81^{\circ} \mathrm{W}\right)$ & Tropical Wet Forests & Forest/trees & $5-10(\mathrm{E})$ & 5.5 \\
\hline Glacier, $\mathrm{MO}\left(49^{\circ} \mathrm{N}, 114^{\circ} \mathrm{W}\right)$ & NW Forested Mountains & Lichens & $2.5-7.1(\mathrm{R})$ & \\
\hline Grand Canyon, $\mathrm{AZ}\left(36^{\circ} \mathrm{N}, 113^{\circ} \mathrm{W}\right)$ & North American Deserts & Herbaceous plants & $3-8.4(\mathrm{~F})$ & \\
\hline Grand Teton, WY $\left(44^{\circ} \mathrm{N}, 111^{\circ} \mathrm{W}\right)$ & NW Forested Mountains & Lichens & $2.5-7.1(\mathrm{R})$ & 2.9 \\
\hline Great Basin, NV $\left(39^{\circ} \mathrm{N}, 114^{\circ} \mathrm{W}\right)$ & North American Deserts & Herbaceous plants & $3-8.4(\mathrm{~F})$ & 1.3 \\
\hline Great Sand Dunes, $\mathrm{CO}\left(38^{\circ} \mathrm{N}, 105^{\circ} \mathrm{W}\right)$ & NW Forested Mountains & Lichens & $2.5-7.1(\mathrm{R})$ & 2.6 \\
\hline $\begin{array}{l}\text { Great Smoky Mountains, } \\
\mathrm{NC}, \mathrm{TN}\left(36^{\circ} \mathrm{N}, 83^{\circ} \mathrm{W}\right)\end{array}$ & Eastern Temperate Forests & Hardwood forest & $3-8(\mathrm{R})$ & 13.6 \\
\hline Guadalupe Mountains, $\mathrm{TX}\left(32^{\circ} \mathrm{N}, 105^{\circ} \mathrm{W}\right)$ & North American Deserts & Herbaceous plants & $3-8.4(\mathrm{~F})$ & 3.1 \\
\hline Hot Springs, AR $\left(34^{\circ} \mathrm{N}, 93^{\circ} \mathrm{W}\right)$ & Eastern Temperate Forests & Hardwood forest & $3-8(\mathrm{R})$ & 10.8 \\
\hline Isle Royale, MI $\left(48^{\circ} \mathrm{N}, 88^{\circ} \mathrm{W}\right)$ & Northern Forests & Hardwood forest & $3-8(\mathrm{~F})$ & 4.2 \\
\hline Joshua Tree, CA $\left(34^{\circ} \mathrm{N}, 116^{\circ} \mathrm{W}\right)$ & North American Deserts & Herbaceous plants & $3-8.4(\mathrm{~F})$ & 3.8 \\
\hline Kings Canyon, $\mathrm{CA}\left(37^{\circ} \mathrm{N}, 118^{\circ} \mathrm{W}\right)$ & NW Forested Mountains & Lichens & $2.5-7.1(\mathrm{R})$ & 2.5 \\
\hline Lassen Volcanic, $\mathrm{CA}\left(40^{\circ} \mathrm{N}, 121^{\circ} \mathrm{W}\right)$ & NW Forested Mountains & Lichens & $2.5-7.1(\mathrm{R})$ & 3.4 \\
\hline Mammoth Cave, $\mathrm{KY}\left(37^{\circ} \mathrm{N}, 86^{\circ} \mathrm{W}\right)$ & Eastern Temperate Forests & Hardwood forest & $3-8(\mathrm{R})$ & 12.1 \\
\hline Mesa Verde, $\mathrm{CO}\left(37^{\circ} \mathrm{N}, 108^{\circ} \mathrm{W}\right)$ & North American Deserts & Herbaceous plants & $3-8.4(\mathrm{~F})$ & 2.9 \\
\hline Mount Rainier, WA $\left(47^{\circ} \mathrm{N}, 122^{\circ} \mathrm{W}\right)$ & NW Forested Mountains & Lichens & $2.5-7.1(\mathrm{R})$ & 6.7 \\
\hline North Cascades, WA $\left(49^{\circ} \mathrm{N}, 121^{\circ} \mathrm{W}\right)$ & NW Forested Mountains & Lichens & $2.5-7.1(\mathrm{R})$ & 4.2 \\
\hline Olympic, WA $\left(48^{\circ} \mathrm{N}, 123^{\circ} \mathrm{W}\right)$ & Marine West Coast Forest & Lichens & $2.7-9.2(\mathrm{R})$ & 3 \\
\hline Petrified Forest, $\mathrm{AZ}\left(35^{\circ} \mathrm{N}, 110^{\circ} \mathrm{W}\right)$ & North American Deserts & Herbaceous plants & $3-8.4(\mathrm{~F})$ & 2.5 \\
\hline Redwood, CA $\left(41^{\circ} \mathrm{N}, 124^{\circ} \mathrm{W}\right)$ & Marine West Coast Forest & Lichens & $2.7-9.2(\mathrm{R})$ & 2.4 \\
\hline Rocky Mountain, $\mathrm{CO}\left(40^{\circ} \mathrm{N}, 106^{\circ} \mathrm{W}\right)$ & NW Forested Mountains & Lichens & $2.5-7.1(\mathrm{R})$ & 4.4 \\
\hline Saguaro, $\mathrm{AZ}\left(32^{\circ} \mathrm{N}, 110^{\circ} \mathrm{W}\right)$ & North American Deserts & Herbaceous plants & $3-8.4(\mathrm{~F})$ & 3 \\
\hline Sequoia, CA $\left(36^{\circ} \mathrm{N}, 119^{\circ} \mathrm{W}\right)$ & NW Forested Mountains & Lichens & $2.5-7.1(\mathrm{R})$ & 4 \\
\hline Shenandoah, VA $\left(38^{\circ} \mathrm{N}, 78^{\circ} \mathrm{W}\right)$ & Eastern Temperate Forests & Hardwood forest & $3-8(\mathrm{R})$ & 14 \\
\hline Theodore Roosevelt, ND $\left(47^{\circ} \mathrm{N}, 103^{\circ} \mathrm{W}\right)$ & Great Plains & Tallgrass prairie & $5-15(F)$ & 3.4 \\
\hline Voyageurs, $\mathrm{MN}\left(48^{\circ} \mathrm{N}, 93^{\circ} \mathrm{W}\right)$ & Northern Forests & Forest/trees & $3-8(\mathrm{~F})$ & 5 \\
\hline Wind Cave, SD $\left(44^{\circ} \mathrm{N}, 103^{\circ} \mathrm{W}\right)$ & Great Plains & Tallgrass prairie & $5-15(\mathrm{~F})$ & 2.8 \\
\hline Yellowstone, WY, MT, ID $\left(45^{\circ} \mathrm{N}, 110^{\circ} \mathrm{W}\right)$ & NW Forested Mountains & Lichens & $2.5-7.1(\mathrm{R})$ & 2.6 \\
\hline Yosemite, CA $\left(38^{\circ} \mathrm{N}, 119^{\circ} \mathrm{W}\right)$ & NW Forested Mountains & Lichens & $2.5-7.1(\mathrm{R})$ & 2 \\
\hline Zion, UT $\left(37^{\circ} \mathrm{N}, 113^{\circ} \mathrm{W}\right)$ & North American Deserts & Herbaceous plants & $3-8.4(\mathrm{~F})$ & 2.6 \\
\hline
\end{tabular}

${ }^{a}$ Level I Ecoregions from the Commission for Environmental Cooperation (CEC, 1997).

$\mathrm{b}$ Ranges of critical loads for different effects on the most sensitive ecosystem receptors in the park, based on the work of Pardo et al. (2011a) and using their level of confidence: $\mathrm{R} \equiv$ reliable, $\mathrm{F} \equiv$ fairly reliable, $\mathrm{E} \equiv$ expert judgment. We use the lower end of the range as measure of critical load in our work (see text). 

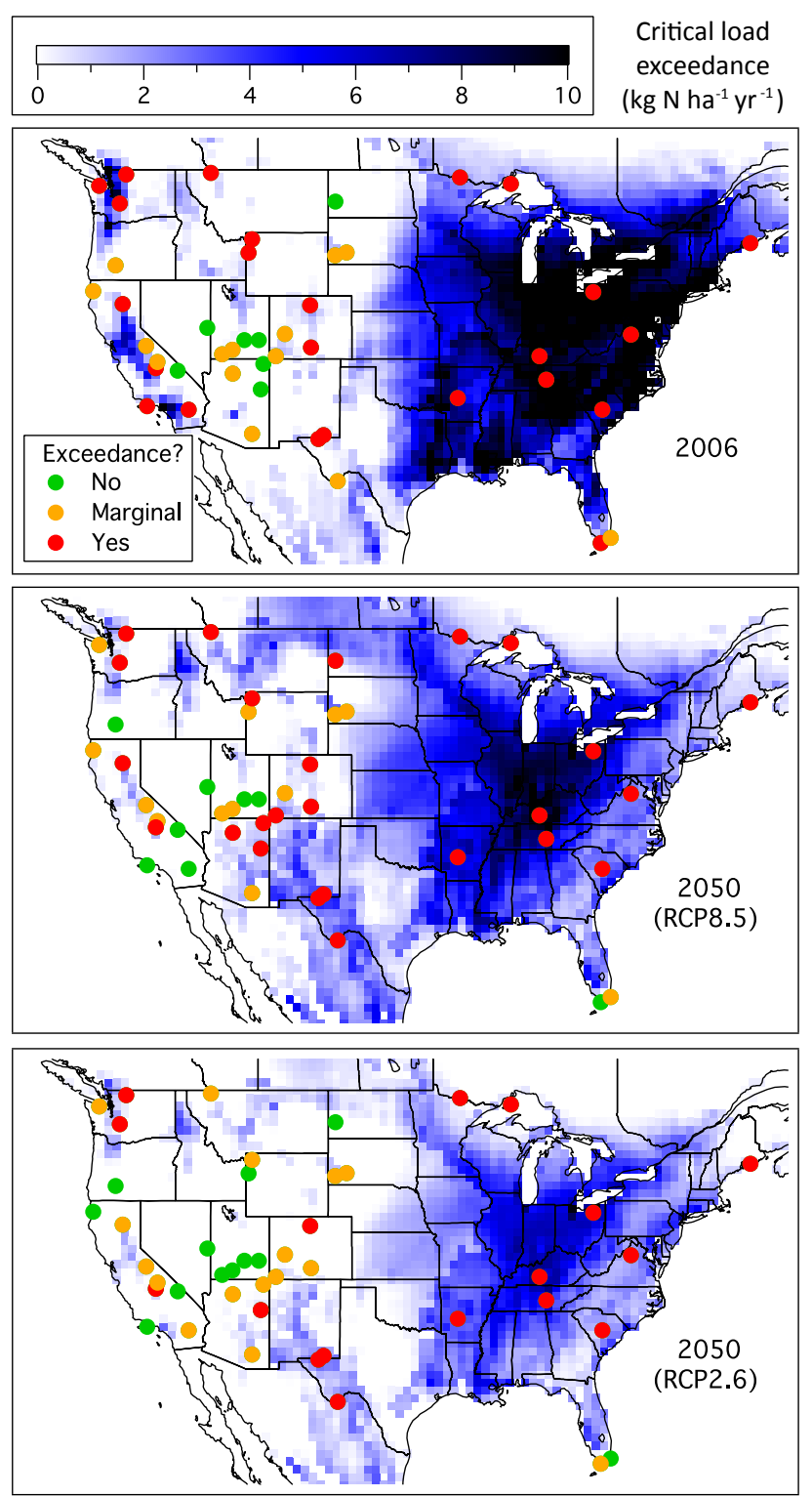

Fig. 5. Critical load exceedance (= total deposition - critical load) for nitrogen deposition in 2006 (top) and 2050 using RCP8.5 (middle) and RCP2.6 (bottom) scenarios. National parks with CL exceedance are shown in red, and those with no CL exceedance are shown in green. Marginal cases where the park itself does not have CL exceedance but an adjacent model grid square does $(\sim 50 \mathrm{~km}$ away) are shown in orange.

either spatially or in magnitude. The increase in the US is mainly due to increases in fertilizer use and livestock driven by a growing population and thus higher food demand (K. Riahi and D. P. van Vuuren, personal communication, 2013). This can be partly offset by expansion of forests, which is a significant part of the carbon emission mitigation strategy in RCP4.5 (Thomson et al., 2011).

We choose to conduct GEOS-Chem simulations for 2050 with the RCP8.5 and RCP2.6 scenarios. RCP8.5 has the
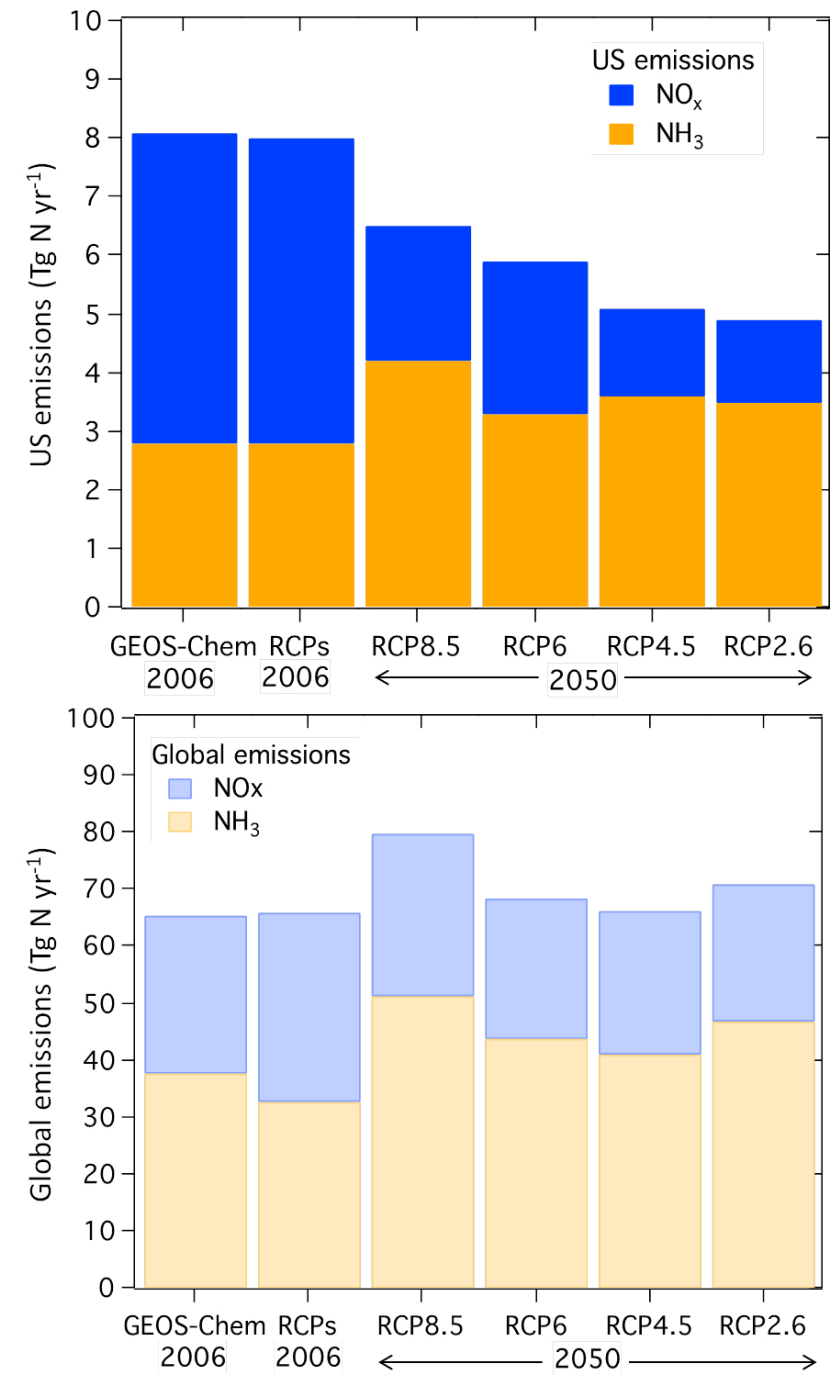

Fig. 6. Present and future anthropogenic $\mathrm{NO}_{\mathrm{x}}$ and $\mathrm{NH}_{3}$ emissions in the contiguous US and globally. The 2006 estimates from GEOSChem (2006) are compared to the corresponding estimate from the RCPs (interpolated 2000-2010 values) and to future RCP projections for 2050 in different scenarios (see text).

highest US and global N emissions for 2050. RCP2.6 has the lowest $\mathrm{N}$ emissions over the US, mainly because of the low overall $\mathrm{NO}_{\mathrm{x}}$ emissions. Our simulations use the same meteorology and natural sources as in our 2006 base case and thus the only change is in the anthropogenic emissions. RCP scenarios also project future biomass burning but here we retained the 2006 GEOS-Chem values (Table 1), as fires in the US are considered natural. We do not consider effects of climate change on transport and precipitation patterns; these effects are uncertain including in their sign (Jacob and Winner, 2009).

Figure 7 shows the projected $\mathrm{N}$ deposition in 2050 using RCP8.5 and RCP2.6 emissions (top). Also shown are the percent contribution from $\mathrm{NH}_{\mathrm{x}}$ (middle) and the difference 


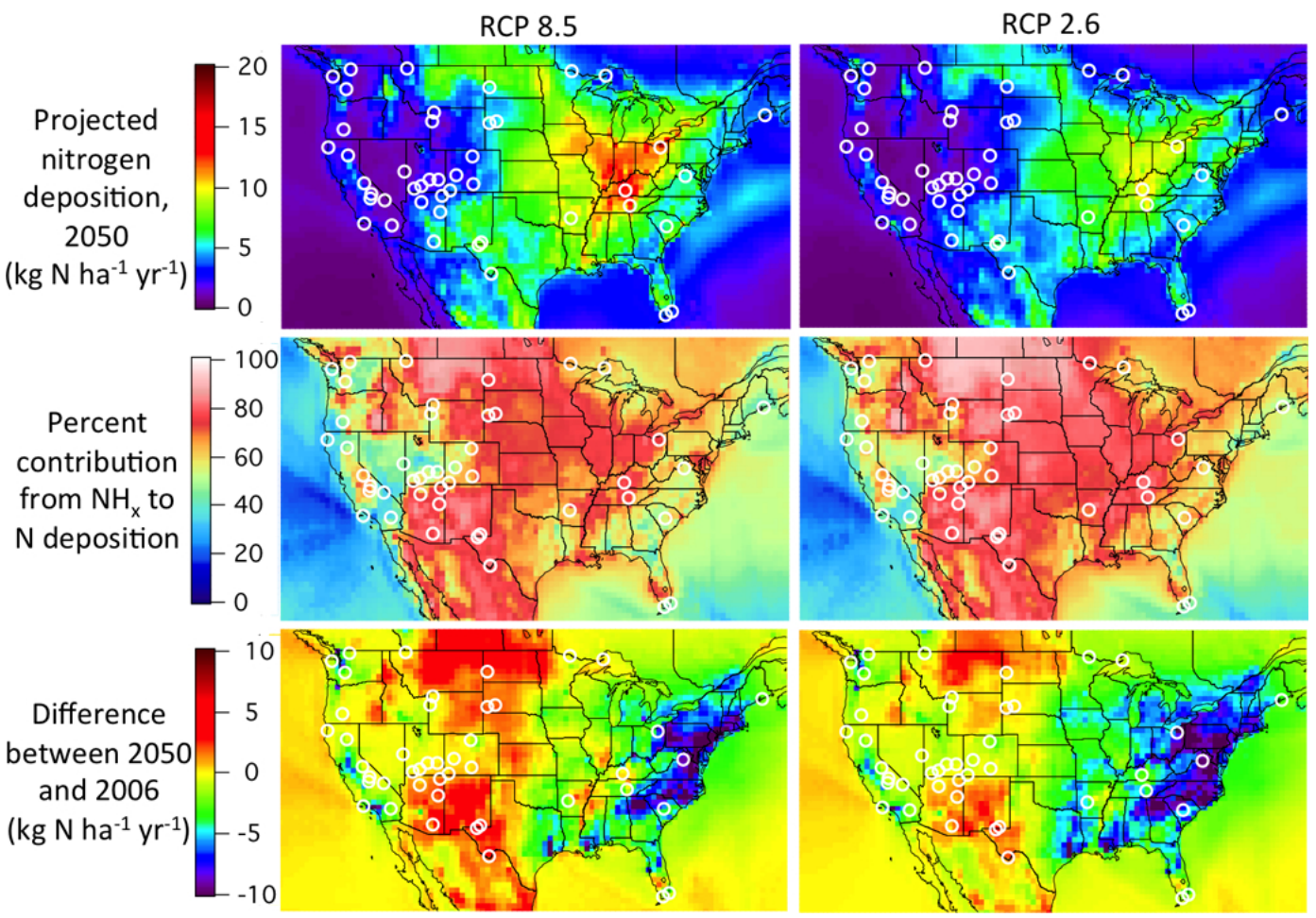

Fig. 7. Projected annual nitrogen deposition in 2050 using RCP 8.5 and RCP 2.6 emission scenarios. The top panels give the total nitrogen deposition, the middle panels show the percent contribution from ammonia $\left(\mathrm{NH}_{\mathrm{x}}\right)$, and the bottom panels show the difference with our 2006 simulation. Circles represent national parks.

with present-day (2006) deposition (bottom). Deposition decreases from 2006 to 2050 in the eastern US and along the west coast, reflecting the decreases in $\mathrm{NO}_{\mathrm{x}}$ emissions. However, increases are projected across much of the Intermountain West. There, RCP $\mathrm{NO}_{\mathrm{x}}$ emissions are small and $\mathrm{NH}_{3}$ emissions are large (Fig. 1). Ammonia dominates 2050 deposition everywhere except along the west and east coasts, in sharp contrast to present-day when $\mathrm{NO}_{\mathrm{x}}$ dominates (Fig. 4). The percent contribution of $\mathrm{NH}_{\mathrm{x}}$ is higher in $\mathrm{RCP} 2.6$ because the $\mathrm{NO}_{\mathrm{x}}$ emissions are lower than in RCP8.5; It reaches up to $85 \%$ at Theodore Roosevelt NP in North Dakota.

Figure 5 gives the CL exceedance maps for 2050 projected from the RCP8.5 (middle) and RCP2.6 (bottom) emission scenarios. There is major improvement relative to 2006 in the East but some degradation in the West, particularly in the Great Plains and the southwest where $\mathrm{NH}_{3}$ emissions increase. Concerns over CL exceedance in US national parks will persist. In 2006, we found 38 parks with a CL exceedance or marginal CL exceedance; in 2050, we find 37 such parks for RCP8.5 and 33 parks for RCP2.6. Parks in the eastern US continue to exceed the CL although there are improvements. For example, at Cuyahoga Valley NP, N deposition exceeds the CL by $7-9 \mathrm{~kg} \mathrm{Nha}^{-1} \mathrm{yr}^{-1}$ in 2050 vs. $15 \mathrm{~kg} \mathrm{Nha}^{-1} \mathrm{yr}^{-1}$ in 2006 . In the Intermountain West, the number of parks with a CL exceedance increases in the RCP8.5 scenario but decreases in the RCP2.6 scenario.
Rocky Mountain NP continues to exceed the CL under both scenarios. California parks show improvements under both scenarios.

The increasing importance of agricultural $\mathrm{NH}_{3}$ emissions in causing $\mathrm{CL}$ exceedance at national parks needs to be emphasized. By 2050, $\mathrm{NH}_{3}$ emissions are projected to account for over $70 \%$ of $\mathrm{N}$ deposition in much of the country, and can alone cause a CL exceedance or marginal exceedance at 18 parks (RCP8.5) or 14 parks (RCP2.6). Even if anthropogenic $\mathrm{NO}_{\mathrm{x}}$ emissions were globally zero, avoiding CL exceedance at all national parks would require a $55 \%$ reduction of US anthropogenic $\mathrm{NH}_{3}$ emissions relative to $2050 \mathrm{RCP} 2.6$ values.

\section{Policy implications}

National parks in the US are by statute to be preserved in their natural state for future generations. Critical loads (CL) provide a metric to estimate the amount of $\mathrm{N}$ deposition that ecosystems can tolerate without harm over the long term. By focusing on the ecosystem receptors most sensitive to $\mathrm{N}$ deposition and using CL estimates from Pardo et al. (2011a) for different ecoregions and receptors, we select CL values in the range $2.5-5 \mathrm{~kg} \mathrm{~N} \mathrm{ha}^{-1} \mathrm{yr}^{-1}$ for the different parks. This is lower than the value of $10 \mathrm{~kg} \mathrm{Nha}^{-1} \mathrm{yr}^{-1}$ commonly 
assumed in $\mathrm{N}$ deposition modeling studies (Lamarque et al., 2005; Dentener et al., 2006). Choice of an appropriate CL is ultimately a matter of policy. Our work shows the implications of using a conservative estimate as may be appropriate for national parks.

Total $\mathrm{N}$ deposition in national parks is not conveniently observed (particularly the dry component) and must therefore be estimated from models. We used here the GEOSChem global model with $1 / 2^{\circ} \times 2 / 3^{\circ}$ horizontal resolution over North America and successfully evaluated it with available observations. We find that 24 out of 45 US national parks have a CL exceedance. Another 14 have a marginal CL exceedance (adjacent model grid squares $\sim 50 \mathrm{~km}$ away are in $\mathrm{CL}$ exceedance). Most of the deposition is from $\mathrm{NO}_{\mathrm{x}}$ emissions, although $\mathrm{NH}_{3}$ emissions dominate in much of the central US. Dry deposition usually accounts for most of total N deposition and this represents an important source of uncertainty, particularly in the West. Better understanding is also needed of $\mathrm{N}$ cycling between the atmosphere and terrestrial ecosystems, as increased $\mathrm{N}$ deposition is expected to drive increased re-emission (not accounted here) that would extend the range of influence from a particular anthropogenic source.

US anthropogenic emissions of $\mathrm{NO}_{\mathrm{x}}$ are presently decreasing in response to clean air regulations targeted at surface ozone. This decrease is expected to continue in the future. Foreign anthropogenic emissions of $\mathrm{NO}_{\mathrm{x}}$ may not similarly decrease but make little contribution to $\mathrm{N}$ deposition in the US. As a result, we expect an increasing relative contribution of agricultural $\mathrm{NH}_{3}$ to $\mathrm{N}$ deposition in the US in the future. No action is presently planned to control US agricultural emissions of $\mathrm{NH}_{3}$, although such actions have been taken in Europe (Bull and Sutton, 1998).

We projected $\mathrm{N}$ deposition in the US in 2050 by using the Representative Concentrations Pathways (RCP) scenarios described in van Vuuren et al. (2011). These scenarios show continued declines in US $\mathrm{NO}_{\mathrm{x}}$ emissions, but increases in $\mathrm{NH}_{3}$ emissions in the US and globally. GEOS-Chem simulations for the RCP8.5 and RCP2.6 scenarios show a major improvement in $\mathrm{N}$ deposition in the East but little progress in the West with some areas experiencing increases. We project from these scenarios that CL exceedance will occur at 1725 US national parks in 2050, as compared to 24 at present. Control of $\mathrm{NH}_{3}$ emissions will be critical for progress. Even in the absence of anthropogenic $\mathrm{NO}_{\mathrm{x}}$ emissions, 14 parks would still have a CL exceedance under the RCP2.6 scenario. Returning all parks to $\mathrm{N}$ deposition below CL would require a $55 \%$ decrease in US anthropogenic $\mathrm{NH}_{3}$ emissions from 2050 RCP2.6 levels.

The US EPA is presently considering a secondary standard for oxides of $\mathrm{N}\left(\mathrm{NO}_{\mathrm{y}}\right)$ based on their impact on ecosystems (US EPA, 2008). Such a standard may drive a faster decrease in the $\mathrm{NO}_{\mathrm{y}}$ contribution to $\mathrm{N}$ deposition than would be achieved from the primary standard protecting public health, and may be of particular benefit in California and in the east- ern US where $\mathrm{NO}_{\mathrm{y}}$ dominates $\mathrm{N}$ deposition. However, our results suggest that the benefit of these actions will be limited without a parallel plan to decrease $\mathrm{NH}_{3}$ emissions.

There are several priority avenues for future work. Better understanding of $\mathrm{NH}_{3}$ dry deposition and its coupling to the terrestrial $\mathrm{N}$ cycle is critical. In our work we viewed deposition as a terminal sink for anthropogenic $\mathrm{N}$, effectively assuming eventual removal from the receptor ecosystem by denitrification or runoff. However, some of the $\mathrm{N}$ will be reemitted as $\mathrm{NH}_{3}$ or $\mathrm{NO}_{\mathrm{x}}$. Improved model schemes have been recently developed to account for bidirectional fluxes of $\mathrm{NH}_{3}$ (Massad et al., 2010; Bash et al., 2013; Flechard et al., 2013) and to relate soil $\mathrm{NO}_{\mathrm{x}}$ emissions to $\mathrm{N}$ deposition (Hudman et al., 2012). A major development would be to use a fully coupled atmosphere-land model to track the fate of anthropogenic $\mathrm{N}$ as it cycles between the atmosphere and terrestrial ecosystems. Such a model could eventually lead to a better understanding of critical loads for ecosystems as related to atmospheric deposition. Better information is also needed on the factors expected to determine $\mathrm{NH}_{3}$ emission in the future, including projections of agricultural activity and fertilizer use in different sectors.

Acknowledgements. This work was funded by the NASA Applied Sciences Program as part of the Air Quality Applied Sciences Team (AQAST). We thank Eladio Knipping (EPRI) for valuable comments.

Edited by: D. Spracklen

\section{References}

Aber, J. D., Goodale, C. L., Ollinger, S. V., Smith, M. L., Magill, A. H., Martin, M. E., Hallett, R. A., and Stoddard, J. L.: Is nitrogen deposition altering the nitrogen status of northeastern forests?, Bioscience, 53, 375-389, 2003.

Baron, J. S.: Hindcasting nitrogen deposition to determine an ecological critical load, Ecol. Appl., 16, 433-439, 2006.

Baron, J. S., Driscoll, C. T., Stoddard, J. L., and Richer, E. E.: Empirical Critical Loads of Atmospheric Nitrogen Deposition for Nutrient Enrichment and Acidification of Sensitive US Lakes, Bioscience, 61, 602-613, doi:10.1525/Bio.2011.61.8.6, 2011.

Bash, J. O., Cooter, E. J., Dennis, R. L., Walker, J. T., and Pleim, J. E.: Evaluation of a regional air-quality model with bidirectional $\mathrm{NH}_{3}$ exchange coupled to an agroecosystem model, Biogeosciences, 10, 1635-1645, doi:10.5194/bg-10-1635-2013, 2013.

Beem, K. B., Raja, S., Schwandner, F. M., Taylor, C., Lee, T., Sullivan, A. P., Carrico, C. M., McMeeking, G. R., Day, D., Levin, E., Hand, J., Kreidenweis, S. M., Schichtel, B., Malm, W. C., and Collett, J. L.: Deposition of reactive nitrogen during the Rocky Mountain Airborne Nitrogen and Sulfur (RoMANS) study, Environ. Pollut., 158, 862-872, doi:10.1016/J.Envpol.2009.09.023, 2010.

Bowman, W. D., Murgel, J., Blett, T., and Porter, E.: Nitrogen critical loads for alpine vegetation and soils in Rocky 
Mountain National Park, J. Environ. Manage., 103, 165-171, doi:10.1016/J.Jenvman.2012.03.002, 2012.

Bull, K. R. and Sutton, M. A.: Critical loads and the relevance of ammonia to an effects-based nitrogen Protocol, Atmos. Environ., 32, 565-572, doi:10.1016/S1352-2310(97)00167-2, 1998.

Burns, D. A., Blett, T., Haeuber, R., and Pardo, L. H.: Critical loads as a policy tool for protecting ecosystems from the effects of air pollutants, Front. Ecol. Environ., 6, 156-159, doi:10.1890/070040, 2008.

Cape, J. N., Cornell, S. E., Jickells, T. D., and Nemitz, E.: Organic nitrogen in the atmosphere - Where does it come from? A review of sources and methods, Atmos. Res., 102, 30-48, doi:10.1016/J.Atmosres.2011.07.009, 2011.

Chen, D., Wang, Y., McElroy, M. B., He, K., Yantosca, R. M., and Le Sager, P.: Regional CO pollution and export in China simulated by the high-resolution nested-grid GEOS-Chem model, Atmos. Chem. Phys., 9, 3825-3839, doi:10.5194/acp-9-3825-2009, 2009.

Dentener, F., Drevet, J., Lamarque, J. F., Bey, I., Eickhout, B., Fiore, A. M., Hauglustaine, D., Horowitz, L. W., Krol, M., Kulshrestha, U. C., Lawrence, M., Galy-Lacaux, C., Rast, S., Shindell, D., Stevenson, D., Van Noije, T., Atherton, C., Bell, N., Bergman, D., Butler, T., Cofala, J., Collins, B., Doherty, R., Ellingsen, K., Galloway, J., Gauss, M., Montanaro, V., Muller, J. F., Pitari, G., Rodriguez, J., Sanderson, M., Solmon, F., Strahan, S., Schultz, M., Sudo, K., Szopa, S., and Wild, O.: Nitrogen and sulfur deposition on regional and global scales: A multimodel evaluation, Global Biogeochem. Cy., 20, Gb4003 doi:10.1029/2005gb002672, 2006.

Driscoll, C. T., Lawrence, G. B., Bulger, A. J., Butler, T. J., Cronan, C. S., Eagar, C., Lambert, K. F., Likens, G. E., Stoddard, J. L., and Weathers, K. C.: Acidic deposition in the northeastern United States: Sources and inputs, ecosystem effects, and management strategies, Bioscience, 51, 180-198, doi:10.1641/00063568(2001)051[0180:Aditnu]2.0.Co;2, 2001.

Ecological Regions of North America: Towards a Common Perspective, Commission for Environmental Cooperation, $71 \mathrm{pp}$., 1997.

Fenn, M. E., Baron, J. S., Allen, E. B., Rueth, H. M., Nydick, K. R., Geiser, L., Bowman, W. D., Sickman, J. O., Meixner, T., Johnson, D. W., and Neitlich, P.: Ecological effects of nitrogen deposition in the western United States, Bioscience, 53, 404-420, 2003a.

Fenn, M. E., Haeuber, R., Tonnesen, G. S., Baron, J. S., GrossmanClarke, S., Hope, D., Jaffe, D. A., Copeland, S., Geiser, L., Rueth, H. M., and Sickman, J. O.: Nitrogen emissions, deposition, and monitoring in the western United States, Bioscience, 53, 391403, 2003b.

Fenn, M. E., Allen, E. B., Weiss, S. B., Jovan, S., Geiser, L. H., Tonnesen, G. S., Johnson, R. F., Rao, L. E., Gimeno, B. S., Yuan, F., Meixner, T., and Bytnerowicz, A.: Nitrogen critical loads and management alternatives for $\mathrm{N}$-impacted ecosystems in California, J. Environ. Manage., 91, 2404-2423, doi:10.1016/J.Jenvman.2010.07.034, 2010.

Fisher, J. A., Jacob, D. J., Wang, Q, Bahreini, R, Carouge, C. C., Cubison, M. J., Dibb, J., Diehl, T., Jimenez, J. L., Leibensperger, E. M., Lu, Z., Meinders, M. B. J., Pye, H. O. T., Quinn, P. K., Sharma, S., Streets, D. J., van Donkelaar, A., and Yantosca, R. M.: Sources, distribution, and acidity of sulfate-ammonium aerosol in the Arctic in winter-spring, Atmos. Environ., 45, 7301-7318, doi:10.1016/j.atmosenv.2011.08.030, 2011.

Flechard, C. R., Massad, R.-S., Loubet, B., Personne, E., Simpson, D., Bash, J. O., Cooter, E. J., Nemitz, E., and Sutton, M. A.: Advances in understanding, models and parameterisations of biosphere-atmosphere ammonia exchange, Biogeosciences Discuss., 10, 5385-5497, doi:10.5194/bgd-10-5385-2013, 2013.

Galloway, J. N., Aber, J. D., Erisman, J. W., Seitzinger, S. P., Howarth, R. W., Cowling, E. B., and Cosby, B. J.: The nitrogen cascade, Bioscience, 53, 341-356, doi:10.1641/00063568(2003)053[0341:Tnc]2.0.Co;2, 2003.

Galloway, J. N., Dentener, F. J., Capone, D. G., Boyer, E. W., Howarth, R. W., Seitzinger, S. P., Asner, G. P., Cleveland, C. C., Green, P. A., Holland, E. A., Karl, D. M., Michaels, A. F., Porter, J. H., Townsend, A. R., and Vorosmarty, C. J.: Nitrogen cycles: past, present, and future, Biogeochemistry, 70, 153-226, 2004.

Gebhart, K. A., Schichtel, B. A., Malm, W. C., Barna, M. G., Rodriguez, M. A., and Collett, J. L.: Back-trajectory-based source apportionment of airborne sulfur and nitrogen concentrations at Rocky Mountain National Park, Colorado, USA, Atmos. Environ., 45, 621-633, doi:10.1016/J.Atmosenv.2010.10.035, 2011.

Geiser, L. H., Jovan, S. E., Glavich, D. A., and Porter, M. K.: Lichen-based critical loads for atmospheric nitrogen deposition in Western Oregon and Washington Forests, USA, Environ. Pollut., 158, 2412-2421, doi:10.1016/J.Envpol.2010.04.001, 2010.

Gilliland, A. B., Appel, K. W., Pinder, R. W., and Dennis, R. L.: Seasonal NH3 emissions for the continental united states: Inverse model estimation and evaluation, Atmos. Environ., 40, 49864998, doi:10.1016/j.atmosenv.2005.12.066, 2006.

Groffman, P., Baron, J., Blett, T., Gold, A., Goodman, I., Gunderson, L., Levinson, B., Palmer, M., Paerl, H., Peterson, G., Poff, N., Rejeski, D., Reynolds, J., Turner, M., Weathers, K., and Wiens, J.: Ecological thresholds: The key to successful environmental management or an important concept with no practical application?, Ecosystems, 9, 1-13, doi:10.1007/S10021-0030142-Z, 2006.

Heald, C. L., J. L. Collett Jr., Lee, T., Benedict, K. B., Schwandner, F. M., Li, Y., Clarisse, L., Hurtmans, D. R., Van Damme, M., Clerbaux, C., Coheur, P.-F., Philip, S., Martin, R. V., and Pye, H. O. T.: Atmospheric ammonia and particulate inorganic nitrogen over the United States, Atmos. Chem. Phys., 12, 10295-10312, doi:10.5194/acp-12-10295-2012, 2012.

Holmes, C. D., Prather, M. J., Søvde, O. A., and Myhre, G.: Future methane, hydroxyl, and their uncertainties: key climate and emission parameters for future predictions, Atmos. Chem. Phys., 13, 285-302, doi:10.5194/acp-13-285-2013, 2013.

Hudman, R. C., Moore, N. E., Mebust, A. K., Martin, R. V., Russell, A. R., Valin, L. C., and Cohen, R. C.: Steps towards a mechanistic model of global soil nitric oxide emissions: implementation and space based-constraints, Atmos. Chem. Phys., 12, 7779-7795, doi:10.5194/acp-12-7779-2012, 2012.

Jacob, D. J. and Winner, D. A.: Effect of climate change on air quality, Atmos. Environ., 43, 51-63, doi:10.1016/j.atmosenv.2008.09.051, 2009.

Kuhns, H., Knipping, E. M., and Vukovich, J. M.: Development of a United States-Mexico emissions inventory for the Big Bend Regional Aerosol and Visibility Observational (BRAVO) Study, J. Air Waste Manage., 55, 677-692, 2005. 
Lamarque, J. F., Kiehl, J. T., Brasseur, G. P., Butler, T., CameronSmith, P., Collins, W. D., Collins, W. J., Granier, C., Hauglustaine, D., Hess, P. G., Holland, E. A., Horowitz, L., Lawrence, M. G., McKenna, D., Merilees, P., Prather, M. J., Rasch, P. J., Rotman, D., Shindell, D., and Thornton, P.: Assessing future nitrogen deposition and carbon cycle feedback using a multimodel approach: Analysis of nitrogen deposition, J. Geophys. Res.-Atmos., 110, D19303, doi:10.1029/2005jd005825, 2005.

Lehmann, C. M. B., Bowersox, V. C., Larson, R. S., and Larson, S. M.: Monitoring Long-term Trends in Sulfate and Ammonium in US Precipitation: Results from the National Atmospheric Deposition Program/National Trends Network, Water Air Soil Poll., 7, 59-66, doi:10.1007/s11267-006-9100-z, 2007.

Massad, R.-S., Nemitz, E., and Sutton, M. A.: Review and parameterisation of bi-directional ammonia exchange between vegetation and the atmosphere, Atmos. Chem. Phys., 10, 10359-10386, doi:10.5194/acp-10-10359-2010, 2010.

Moss, R. H., Edmonds, J. A., Hibbard, K. A., Manning, M. R., Rose, S. K., van Vuuren, D. P., Carter, T. R., Emori, S., Kainuma, M., Kram, T., Meehl, G. A., Mitchell, J. F. B., Nakicenovic, N., Riahi, K., Smith, S. J., Stouffer, R. J., Thomson, A. M., Weyant, J. P., and Wilbanks, T. J.: The next generation of scenarios for climate change research and assessment, Nature, 463, 747-756, doi:10.1038/Nature08823, 2010.

National Park Service Management Policies, Interpreting the Key Statutory Provisions of the 1916 NPS Organic Act: http://www. nps.gov/protect/policy_section.htm, 2001.

Nilsson, J. and Grennfelt, P.: Critical Load for Sulphur and Nitrogen. Report from a workshop at Skoloster, Sweden, NORD Report, Copenhagen, 418 pp., 1988.

Pardo, L. H., Fenn, M. E., Goodale, C. L., Geiser, L. H., Driscoll, C. T., Allen, E. B., Baron, J. S., Bobbink, R., Bowman, W. D., Clark, C. M., Emmett, B., Gilliam, F. S., Greaver, T. L., Hall, S. J., Lilleskov, E. A., Liu, L. L., Lynch, J. A., Nadelhoffer, K. J., Perakis, S. S., Robin-Abbott, M. J., Stoddard, J. L., Weathers, K. C., and Dennis, R. L.: Effects of nitrogen deposition and empirical nitrogen critical loads for ecoregions of the United States, Ecol. Appl., 21, 3049-3082, 2011a.

Pardo, L. H., Robin-Abbott, M. J., and Driscoll, C. T.: Assessment of Nitrogen deposition effects and empirical critical loads of Nitrogen for ecoregions of the United States, Gen. Tech. Rep. NRS80. Newtown Square, PA: U.S. Department of Agriculture, Forest Service, Northern Research Station, 291, $2011 \mathrm{~b}$.

Paulot, F., Jacob, D. J., and Henze, D. K.: Sources and processes contributing to nitrogen deposition in biodiversity hotspots worldwide, Environ. Sci. Technol., 47, 3226-3233, doi:10.1021/es3027727, 2013a.

Paulot, F., Jacob, D. J., Pinder, R. W., Bash, J. O., Travis, K., and Henze, D. K.: Ammonia emissions in the United States, Europe, and China derived by high-resolution inversion of ammonium wet deposition data: Interpretation with a new agricultural emissions inventory (MASAGE_NH3), J. Geophys. Res., submitted, 2013b.

Pinder, R. W., Adams, P. J., Pandis, S. N., and Gilliland, A. B.: Temporally resolved ammonia emission inventories: Current estimates, evaluation tools, and measurement needs, J. Geophys. Res.-Atmos., 111, D16310, doi:10.1029/2005jd006603, 2006.
Porter, E. and Johnson, S.: Translating science into policy: Using ecosystem thresholds to protect resources in Rocky Mountain National Park, Environ. Pollut., 149, 268-280, doi:10.1016/J.Envpol.2007.06.060, 2007.

Porter, E., Blett, T., Potter, D. U., and Huber, C.: Protecting resources on federal lands: Implications of critical loads for atmospheric deposition of nitrogen and sulfur, Bioscience, 55, 603612, 2005.

Rocky Mountain National Park Nitrogen Deposition Reduction Plan, Memorandum of Understanding Agencies: http://www. colorado.gov/cs/Satellite/CDPHE-AP/CBON/1251594862555, 2007.

Rodriguez, M. A., Barna, M. G., Gebhart, K. A., Hand, J. L., Adelman, Z. E., Schichtel, B. A., Collett, J. L., and Malm, W. C.: Modeling the fate of atmospheric reduced nitrogen during the Rocky Mountain Atmospheric Nitrogen and Sulfur Study (RoMANS): Performance evaluation and diagnosis using integrated processes rate analysis, Atmos. Environ., 45, 223-234, doi:10.1016/J.Atmosenv.2010.09.011, 2011.

Saros, J. E., Clow, D. W., Blett, T., and Wolfe, A. P.: Critical Nitrogen Deposition Loads in High-elevation Lakes of the Western US Inferred from Paleolimnological Records, Water Air Soil Poll., 216, 193-202, doi:10.1007/S11270-010-0526-6, 2011.

Thomson, A. M., Calvin, K. V., Smith, S. J., Kyle, G. P., Volke, A., Patel, P., Delgado-Arias, S., Bond-Lamberty, B., Wise, M. A., Clarke, L. E., and Edmonds, J. A.: RCP4.5: a pathway for stabilization of radiative forcing by 2100 , Climatic Change, 109 , 77-94, doi:10.1007/S10584-011-0151-4, 2011.

US EPA (Environmental Protection Agency): Integrated Science Assessment (ISA) for Oxides of Nitrogen and Sulfur-Ecological Criteria (Final Report), EPA/600/R-08/082F, US Environmental Prot Assessment-RTP Division, Office of Research and Development, Research Triangle Park, NC, USA, available at: http: //cfpub.epa.gov/ncea/cfm/recordisplay.cfm?deid=201485, 2008.

van Vuuren, D. P., Edmonds, J., Kainuma, M., Riahi, K., Thomson, A., Hibbard, K., Hurtt, G. C., Kram, T., Krey, V., Lamarque, J. F., Masui, T., Meinshausen, M., Nakicenovic, N., Smith, S. J., and Rose, S. K.: The representative concentration pathways: an overview, Climatic Change, 109, 5-31, doi:10.1007/S10584011-0148-Z, 2011.

Walker, J. M., Philip, S., Martin, R. V., and Seinfeld, J. H.: Simulation of nitrate, sulfate, and ammonium aerosols over the United States, Atmos. Chem. Phys., 12, 11213-11227, doi:10.5194/acp12-11213-2012, 2012.

Wang, Q., Jacob, D. J., Fisher, J. A., Mao, J., Leibensperger, E. M., Carouge, C. C., Le Sager, P., Kondo, Y., Jimenez, J. L., Cubison, M. J., and Doherty, S. J.: Sources of carbonaceous aerosols and deposited black carbon in the Arctic in winter-spring: implications for radiative forcing, Atmos. Chem. Phys., 11, 1245312473, doi:10.5194/acp-11-12453-2011, 2011.

Xing, J., Pleim, J., Mathur, R., Pouliot, G., Hogrefe, C., Gan, C.M., and Wei, C.: Historical gaseous and primary aerosol emissions in the United States from 1990-2010, Atmos. Chem. Phys. Discuss., 12, 30327-30369, doi:10.5194/acpd-12-30327-2012, 2012. 
Zhang, L., Jacob, D. J., Knipping, E. M., Kumar, N., Munger, J. W., Carouge, C. C., van Donkelaar, A., Wang, Y. X., and Chen, D.: Nitrogen deposition to the United States: distribution, sources, and processes, Atmos. Chem. Phys., 12, 4539-4554, doi:10.5194/acp-12-4539-2012, 2012.
Zhu, L., Henze, D. K., Cady-Pereira, K. E., Shephard, M. W., Luo, M., Pinder, R. W., Bash, J. O., Jeong, G.-R.: Constraining U.S. ammonia emissions using TES remote sensing observations and the GEOS-Chem adjoint model, J. Geophys. Res.Atmos., 118, 3355-3368, doi:10.1002/jgrd.50166, 2013. 